\title{
Understanding and Approach towards Breast Feeding (A Study of Rural Nursing Mothers)
}

\author{
Ms Rachana Dutt, Dr Payal Mahajan \\ Department of Nutrition \& Health, School of Medical and Allied Sciences, GD Goenka University, Gurgaon, \\ India
}

\section{Article Info \\ Volume8, Issue 3 \\ Page Number: 300-305}

\section{Publication Issue}

May-June-2021

\section{Article History}

Accepted : 18 May2021

Published : 24 May2021

\begin{abstract}
A well-known saying "your health will depend on the type of food you eat". A solid eating regimen comprises of an even eating routine made out of exceedingly significant supplements in right extent. It forestalls lack of healthy sustenance and beginning of illnesses like weight, diabetes, heart ailments, disease and stroke to give some examples. Newborn child and little youngster taking care of practices are of prime significance to keep up the dietary status of kids between 0-24 months of age and are frequently affected by conventional practices. Baby and small kid taking care of practices, lack of healthy sustenance and kid endurance rates in the nation are interlinked. Accentuation on improving these practices is a basic advance for better advancement and wellbeing of children. Contamination and ailing health during the pinnacle time of advancement in the initial two years of life influence the development capability of kids. Breastfeeding is an essential human action, crucial to newborn child and maternal wellbeing also, of monstrous financial incentive to families and societies. To survey the healthful information and demeanor towards breast feeding among rural nursing moms, present investigation was led. The example was 200 lactating moms. Purposive Random examining strategy was utilized to gather the data. The information was gathered legitimately from moms by utilizing organized survey to evaluate the dietary information and attitude of nursing mother. After the information assortment, information will be coded efficiently and organized under various heads. Coding was done on the basis of knowledge and attitude. After this, content and statistical analysis was done using percentage.
\end{abstract}

Keywords : Breast feeding Knowledge Attitude

\section{INTRODUCTION}

Breastfeeding, otherwise called nursing, is the taking care of infants and little youngsters with milk from a lady's breast. Wellbeing experts suggest that breastfeeding start inside the primary hour of an infant's life and proceed as regularly and as much as the child needs. 
Breast taking care of is an individual choice a mother needs to make cautiously, considering the advantages and weights it will bring to both mother and child. Breast taking care of offers numerous advantages. It assists infants with getting the correct nourishment and can assist moms with recuperating from pregnancy and conveyance. Critically, breast taking care of can advance a bond? among mother and child. It is assessed that roughly $62 \%$ of mom'sbreast feed their kids. Expecting moms intending to medical caretaker ought to examine breast taking care of with a doctor, nurture, or ensured lactation advisor before conceiving an offspring. A solid infant can profit by breast milk, packaged milk or a mix of the two.

Breast milk gives numerous medical advantages and is the ideal first nourishment for your child. No different fluids or nourishments ought to be given to your infant, including water, sugar water, juice, equation, soups, rice grain or pureed food sources.

The measure of breast milk you make will increment over the initial not many days after birth. Breast milk is the ideal parity of water and supplements containing fats, sugars, proteins, minerals, nutrients, antibodies and catalysts. It is likewise intended to advance cerebrum and body development. As your infant becomes more seasoned, your milk changes to meet your child's wholesome needs.

Breastfeeding likewise permits you and your child to bond in a manner that can't be coordinated by bottle taking care of. Breastfeeding meets both your infant's dietary and sustaining needs.

\section{RESEARCH METHODOLOGY}

To assess the sustaining data and disposition of nursing mothers, present examination was driven in Delhi. The example was included 200 provincial lactating mothers. Purposive Random assessing procedure was used to assemble the information. The data was assembled direct from mothers by using composed review to assess the sustaining data and mentality of nursing mother. After the data collection, data was coded effectively and masterminded under different heads. Coding was done dependent on data and demeanor. After this, content and quantifiable examination was done using rates.

Table 1. SOCIO DEMOGRAPHIC APPEARANCES OF THE RESPONDENTS

\begin{tabular}{|l|l|l|}
\hline Characteristics & $\begin{array}{l}\text { Frequency } \\
\text { (n=200) }\end{array}$ & $\begin{array}{l}\text { Percentages } \\
\text { (\%ages) }\end{array}$ \\
\hline $\begin{array}{l}\text { Age of the } \\
\text { respondents } \\
<25\end{array}$ & 54 & 27 \\
$25-30$ & 106 & 53 \\
$31-35$ & 40 & 20 \\
$36-40$ & - & - \\
\hline Type of Family & 168 & \\
Joint & 32 & 84 \\
Nuclear & & 16 \\
\hline Educational Status & & \\
Matric & 80 & 40 \\
Higher Sec & 60 & 30 \\
Graduation & 40 & 20 \\
Post-Graduation & 20 & 10 \\
Other & - & - \\
& & \\
\hline Occupational Status & & \\
Working & 44 & \\
Not Working & 156 & \\
\hline
\end{tabular}

Table 1 demonstrates that majority of the nursing mothers (53\%) were in the age group of 25-30 years; $27 \%$ were below the age 25 years, 20\% were in the age scope of 31-35 years. Larger part of the respondent's for example $84 \%$ were from joint family and $16 \%$ were from nuclear. Dominant part of them were matriculate i.e. $40 \%$, trailed by higher secondary (30\%) and just $20 \%$ of them were graduates and $10 \%$ were post graduates. 
Table 2. Knowledge of nursing mothers towards Breast feeding

\begin{tabular}{|c|c|c|}
\hline VARIABLES & YES & NO \\
\hline $\begin{array}{l}\text { The baby is given breast feed } \\
\text { soon after his/her birth... }\end{array}$ & $180(90)$ & $20(10)$ \\
\hline $\begin{array}{lll}\text { Do you know about } \\
\text { colostrum? }\end{array}$ & $60(30)$ & $\begin{array}{l}140(70 \\
)\end{array}$ \\
\hline $\begin{array}{l}\text { Do you know that colostrum } \\
\text { fights against diseases? }\end{array}$ & $20(10)$ & $\begin{array}{l}180(90 \\
)\end{array}$ \\
\hline $\begin{array}{l}\text { The prelacteal feed is good } \\
\text { for newly born child like } \\
\text { water honey etc }\end{array}$ & $140(70)$ & $60(30)$ \\
\hline $\begin{array}{l}\text { Is breast milk easily } \\
\text { digestible and acceptable by } \\
\text { infant }\end{array}$ & 180(90) & $20(10)$ \\
\hline $\begin{array}{l}\text { Breast milk is balanced diet } \\
\text { for the infant. }\end{array}$ & 200 & - \\
\hline $\begin{array}{l}\text { Breast feeding helps to } \\
\text { develop strong bond between } \\
\text { mother and child. }\end{array}$ & 152 & $48(24)$ \\
\hline $\begin{array}{l}\text { Breast milk is a clean and } \\
\text { hygienic method of feeding }\end{array}$ & $164(82)$ & $36(18)$ \\
\hline $\begin{array}{l}\text { Breast milk is readily } \\
\text { available for the infant }\end{array}$ & 184 & $66(08)$ \\
\hline $\begin{array}{l}\text { Breast milk is more } \\
\text { economical compared to the } \\
\text { artificial feeding. }\end{array}$ & 192(96) & $08(4)$ \\
\hline $\begin{array}{l}\text { Breast milk provides all } \\
\text { nutrients required by the } \\
\text { child up to } 6 \text { months. }\end{array}$ & $160(80)$ & $40(20)$ \\
\hline $\begin{array}{l}\text { Breast milk protects the child } \\
\text { from illness. }\end{array}$ & $96(48)$ & $\begin{array}{l}104(52 \\
)\end{array}$ \\
\hline $\begin{array}{l}\text { Artificial feeding is better } \\
\text { than breast feeding. }\end{array}$ & $24(14)$ & $\begin{array}{l}176(88 \\
)\end{array}$ \\
\hline $\begin{array}{l}\text { Feeding mothers should have } \\
\text { eat balanced and healthy diet }\end{array}$ & $92(46)$ & $108(54$ \\
\hline $\begin{array}{l}\text { Breast fed babes are } \\
\text { comparatively healthier than } \\
\text { bottle babies }\end{array}$ & $172(86)$ & $28(14)$ \\
\hline
\end{tabular}

\%ages are in parentheses
The above table no 2 that larger part (90\%) of the nursing moms knew about the way that child ought to be given breastfeed following the infant's introduction to the world and majority (70\%) of mothers were not aware about the colostrum and its significance. Other than that majority $(70 \%)$ of them were in favour of giving prelacteal feed to new conceived and accept that breast milk is effectively edible and satisfactory by the baby. Greatest nursing moms were of the supposition that "Breast milk is a best regimen for the newborn child". They additionally included that(76\%) breast feeding builds up a solid bond among mother and her infant. They trust it is helpful, conservative and promptly accessible nourishment for the infant and best of all, it contains all the supplements required by the kid up to a half year. Majority of them believe that "breast feeding is the clean and hygienic method of feeding; readily available \& economical as compared to artificial feeding". They were also well versed with the fact that "breast milk also contains all the essential nutrients required by the baby till 6 months". Surprisingly almost half of the total sample was not aware of the fact that "breast milk protects the child from illness \& feeding mothers should have balanced diet". They were knowledgeable with the way that breast milk shields the kid from sickness and in each angle it is better than counterfeit taking care of as breastfed babies are a lot more grounded than bottle took care of infants. They likewise expressed that nursing moms ought to have solid and adjusted eating routine with the goal that all the fundamental supplements required by the child can be given timely.

Table 3. Approach of nursing mothers towards breast feeding

\begin{tabular}{|l|l|l|}
\hline VARIABLES & YES & NO \\
\hline $\begin{array}{l}\text { Do you think that the baby } \\
\text { should be given breast feed } \\
\text { soon after his/her birth? }\end{array}$ & $172(86)$ & $28(14)$ \\
\hline Do you think that colostrum & $20(10)$ & $180(90)$ \\
\hline
\end{tabular}




\begin{tabular}{|l|l|l|}
\hline should be given to the child? & & \\
\hline $\begin{array}{l}\text { Besides mother's milk, do you } \\
\text { think that prelacteal feed is } \\
\text { needed for the child? }\end{array}$ & $134(67)$ & $66(33)$ \\
\hline $\begin{array}{l}\text { Would you continue with } \\
\text { breast feeding after your } \\
\text { child turns one if the child so } \\
\text { desires? }\end{array}$ & $196(98)$ & $04(02)$ \\
\hline $\begin{array}{l}\text { Would you not breastfeed } \\
\text { your child after he/she turns } \\
\text { two, even if the child so } \\
\text { desires? }\end{array}$ & $120(60)$ & $80(40)$ \\
\hline $\begin{array}{l}\text { Would you feed your child } \\
\text { on demand? }\end{array}$ & $192(96)$ & $08(04)$ \\
\hline $\begin{array}{l}\text { Do you think that working } \\
\text { mothers should introduce } \\
\text { formula milk as well? }\end{array}$ & $80(40)$ & $120(60)$ \\
\hline $\begin{array}{l}\text { Would you stop breastfeeding } \\
\text { your child as soon as you }\end{array}$ & $172(86)$ & $28(14)$ \\
\hline $\begin{array}{l}\text { Do you think that returning } \\
\text { to work would not make you } \\
\text { stop breastfeeding? }\end{array}$ & $194(97)$ & $06(03)$ \\
\hline $\begin{array}{l}\text { If your partner would have } \\
\text { helped you and brought child } \\
\text { to your workplace, wouldyou } \\
\text { breastfeed? }\end{array}$ & $196(98)$ & $04(02)$ \\
\hline
\end{tabular}

\%ages are in parentheses

It is apparent from table 3 that greater part of the moms believed that breast feed should be given immediately after the birth of the child; $20 \%$ demonstrated inspirational disposition towards colostrum. In spite of the fact that $86 \%$ of working moms expressed that they would stop breast feeding (during working hours only)when they began to work since they don't have some other choice close by. They further included that they truly don't want to stop this during office hours however defenseless. Indeed, even non-working moms were of a similar supposition that in case they would be working they would need to quit breast feed during working hours. They believe in breast feeding however all the while they feel that formula milk ought to likewise be presented as it would be advantageous for working moms when they are at their work place; they accept that in the wake of coming originate from work, they are unquestionably going to take care of their infants with special focus on breast feed. In general it has been found that dominant part of them confirmed inspirational appearance towards breast taking care of nonetheless they also accept that there should be some options other than breast feed ought to be there in the event of nonattendance of nursing mother.Indeed, even they indicated uplifting outlook towards breast feeding at the work environment in the event that their accomplices help them and get the kids to their work environment,

\section{DISCUSSION}

This examination shows that mothers who have incredible data towards Breast Feeding. Reason might be qualified mothers, provincial settings and money related status of the individuals. Data by respondents on colostrum in this assessment is $20 \%$ (having worthy data). Similar assessment was driven by Vijayalakshmi, P.et al (2015), dominant part (88.5\%) of the moms were breast feeders. Nonetheless, simply $27 \%$ of the moms were select breast feeders and just barely any rate started breast taking care of inside 60 minutes. While moms have great information on breast taking care of. In the current examination, they recognize that in the wake of coming start from work, they are obviously going to manage their infant youngsters with excellent focus on breast feed. Truth be told, even they demonstrated hoisting perspective towards breast taking care of at the work environment if their partners help them and get the youngsters to their work environment. The current assessment reasons that the mothers have a great data and persuasive attitudes toward breast taking care of. Our disclosures in like manner show that mindset towards restrictive breast milk was insignificant low among these mothers. Along these lines, it is basic to 
give pre-birth directions or rules to mothers and fathers on breast taking care of. Studies show that ladies who have breastfed experience diminished paces of breast and ovarian malignant growth sometime down the road. A couple of assessments have found that breastfeeding may decrease the risk of making type 2 diabetes, rheumatoid joint inflammation, and cardiovascular infection, including hypertension and elevated cholesterol. We in like manner propose sustaining the overall prosperity preparing endeavors to propel breast taking care of practices in India

\section{WAYS OF ENCOURAGING BREAST FEEDING PRACTICES}

1) Compose breastfeeding strategy so that it is regularly imparted to all medical services staff.

2) Train all medical services staff in abilities important to carry out this arrangement.

3) Advise all pregnant ladies about the advantages and the executives of breastfeeding.

4) Help moms start breastfeeding inside a half-hour of birth.

5) Tell moms the best way to breastfeed and how to keep up lactation regardless of whether they ought to be isolated from their babies.

6) Give babies no food or drink other than bosom milk except if medicinally demonstrated.

7) Work on staying in-permit moms and newborn children to stay together-24 hours per day.

8) Empower breastfeeding on request.

9) Even gynecologists \& pediatricians should start guiding the pregnant mothers well in advance

10) Encourage the foundation of breastfeeding support gatherings and allude moms to them on release from the medical clinic or center.

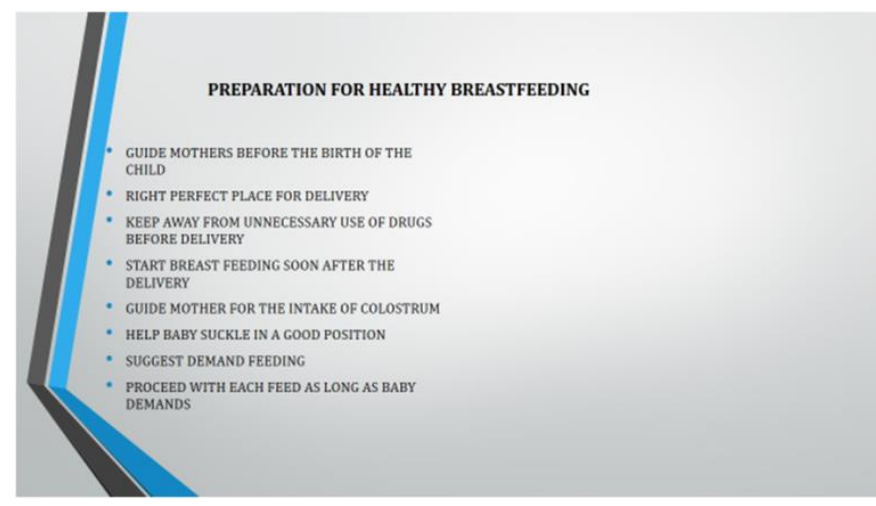

\section{REFERENCES}

[1]. Bhan N.B, Mahajan P, \& Bhadwal Bandana. A comparative study of Breast-Feeding Practices among Kashmiri Pandits and Dogras. The Anthropologist. International Journal of Contemporary and Applied Studies of Man. 2004; 6(4):261-263 3.

[2]. Bautista LE, Rev Panam Salud Publica. Factors associated with the initiation of breast feeding by women in the Dominican Republic]. 1997; 1(3):200-7. [PubMed]

[3]. Daniel YT. Fong...Copyright (C) 2016 Sowmini P. Kamath et al. This is an open access article distributed under the Creative Commons Attribution License, which permits unrestricted use, distribution, and reproduction in any medium, provided the original work is properly cited.

[4]. Department of Paediatrics, Kasturba Medical College, Mangalore, Manipal University, Manipal, India Kasturba Medical College, Mangalore, Manipal University, Manipal, India Department of Community Medicine, Kasturba Medical College, Mangalore, Manipal University, Manipal, India Received 15 December 2015; Revised 4 August 2016; Accepted 29 August 2016

[5]. Mahajan, P and Gupta, R.(2018): Breast feeding awareness among urban women (a comparative study of Gurgaon \& Jammu) International 
Journal of Home Science Vol 4(1); January 2018;

Pp No. 245--248

[6]. Mulugeta, W.A, Netsanet, H.BBayu, NigusieBirhanTebeje, and SelamFisehaKassa( 2017) Knowledge and Attitude towards Exclusive Breast Feeding among Mothers Attending Antenatal and Immunization Clinic at Dabat Health Center, Northwest Ethiopia: A Cross-Sectional Institution Based Study. Article ID6561028

https://doi.org/10.1155/2017/6561028

[7]. Poreddi Vijayalakshmi,T Susheela, and D Mythili: Knowledge, attitudes, and breast feeding practices of postnatal mothers: A cross sectional survey. Int J Health Sci (Qassim). 2015 Oct; 9(4): 364-374.

\section{Cite this Article}

Rachana Dutt, Dr Payal Mahajan, "Understanding and Approach towards Breast Feeding (A Study of Rural Nursing Mothers) ", International Journal of Scientific Research in Science and Technology (IJSRST), Online ISSN : 2395-602X, Print ISSN : 2395-6011, Volume 8 Issue 3, pp. 300-305, May-June 2021. Available at doi : https://doi.org/10.32628/IJSRST218347 Journal URL : https://ijsrst.com/IJSRST218347 